TOMASZ JEŻ

UNIWERSYTET WARSZAWSKI

\title{
MUZYKA W SŁUŻBIE PRZEKAZU WIZUALNEGO W JEZUICKIM DRAMACIE SZKOLNYM ${ }^{1}$
}

\begin{abstract}
Tednym z fenomenów kultury artystycznej pielęgnowanej w środowiskach zakonnych nowożytnej Europy był jezuicki dramat szkolny. Zjawisko to jest przedmiotem niesłabnącego zainteresowania historyków duchowości, literatury, teatru, sztuk wizualnych oraz muzyki, łączy bowiem w sobie elementy wielu dyscyplin sztuki. Jako fenomen swego rodzaju multimedialny ${ }^{2}$, jezuicki dramat wymaga ujęć interdyscyplinarnych, które pozwalają na lepsze rozumienie jego znaczenia, wyrażonego równolegle za pomocą różnych kodów kultury. W perspektywie studiów nad ikonografią muzyczną temat ten jawi się również obiecująco; ujawnia bowiem strukturalne zależności między dyskursem sztuk przedstawiających a narracją słowno-muzyczną. Daleko niesatysfakcjonujący stan zachowania źródeł stricte muzycznych utrudnia podjęcie muzykologicznych studiów nad tym przedmiotem; perspektywa interdyscyplinarna pozwala jednak na przyjrzenie mu się w nieco szerszym kontekście.

Pomaga ona przede wszystkim lepiej zrozumieć rolę, którą w epoce nowożytnej odegrał jezuicki dramat. Rola ta wynikała zaś z zadań, jakie gatunek ów miał pełnić w różnych zakresach oddziaływania jezuickiej misji w kulturze 3 . Obok pielęgnowanej w tym środowisku literatury, malarstwa, rzeźby, architektury i muzyki, sztuka teatralna była szczególnie cenionym środkiem artystycznej wypowiedzi, wiązała bowiem elementy
\end{abstract}

I Niniejszy tekst powstał dzięki grantowi Balzan Research Programme in Musicology „Towards a global history of music”, odbywanemu przeze mnie w styczniu, lutym i marcu 20I5 r. w Oksfordzie i Wiedniu. Chciałbym w tym miejscu wyrazić swą wdzięczność wobec fundatora tego stypendium, prof. Reinharda Strohma, a także o. Thomasa Franka Kennedy'ego SJ z Campion College (Oxford), prof. Herberta Seiferta z Uniwersytetu Wiedeńskiego, dr Andrei Sommer-Mathis z Instytutu Kulturoznawstwa i Historii Teatru Austriackiej Akademii Nauk oraz dr. Matthiasa Pernerstorfera z Don Juan Archiv w Wiedniu, dzięki którym mogłem uzyskać dostęp do licznych źródeł.

2 Barbara Bauer, „Multimediales Theater. Ansätze zu einer Poetik der Synästhesie bei den Jesuiten”, w: Renaissance-Poetik, red. Heinrich F. Plett, Berlin, New York 1994, s. 197-238.

3 John O'Malley, „Saint Ignatius and the cultural mission of the Society of Jesus”, w: The Jesuits. Cultures, sciences, and the arts, I540-I773, red. John W. O’Malley, Gauvin Alexander Bailey, Steven J. Harris, Thomas Frank Kennedy, Toronto I999, s. I-26. 
różnych dyscyplin sztuki w swego rodzaju system wielowątkowej retorycznej perswazji. $\mathrm{Z}$ uwagi na sprawdzoną w praktyce skuteczność tego oddziaływania była ona szeroko eksploatowana w prowadzonej przez jezuitów edukacji, doskonale bowiem służyła wszechstronnemu wykształceniu, odgrywając zarazem niebagatelną rolę w kształtowaniu tożsamości kulturowej wielu pokoleń elit intelektualnych ówczesnego świata ${ }^{4}$.

Sformułowana $\mathrm{w}$ piśmiennictwie teoretycznym poetyka jezuickiego dramatu bazowała na wzorcach arystotelesowskich i horacjańskich; wykraczała jednak poza klasyczne reguły, burząc jedność czasu, mieszając gatunki, wprowadzając elementy nadprzyrodzone i zrywając z nierozwiązywalnym konfliktem racji. By dostosować dramat do wymogów dydaktyki i wrażliwości estetycznej epoki, przebieg fabuły urozmaicały „efekty specjalne”: emblematyczne pegmata, wstawki muzyczne, chór, pantomima (tzw. scenae mutae) oraz balet. Obecność tych elementów musiała jednak naturalnie wynikać z treści akcji i podlegać pragmatyce retorycznej perswazji; ze względu na ten cel jezuicki dramat zbliżał się więc do takich gatunków jak misterium, oratorium czy opera. Teatralny apparatus miał intensyfikować doznania odbiorcy poprzez zespolenie przekazu słownego z wizualnym oraz muzycznym. Takie wielokanałowe oddziaływanie na widza-słuchacza spektaklu pozwalało na niemal podprogowe wywoływanie zakodowanych w języku sztuki afektów i ukrytych treści.

Tej „synestetycznej” poetyce dramatu odpowiadał analogicznie koncypowany sposób oddziaływania religijnego. Jego model i pierwowzór stanowiła ignacjańska metoda applicatio sensuum, angażująca dla potrzeb medytacji religijnej poznanie płynące za przyczyną zmysłów wyobraźni. Odbierane przez nie doznania wykorzystywane były dla wyobrażenia miejsca kontemplowanej treści (compositio loci), jego emocjonalnego odczucia, komplementarnego względem poznania intelektualnego. Jezuicki dramat szkolny był zatem artystycznym odpowiednikiem modlitewnego „teatru wyobraźni”. Pokrewieństwo obu tych form dobitnie podkreśla etymologia pojęcia repraesentatio, odnoszącego się zarówno do świata imaginacji, jak i wydarzeń przedstawianych na scenie teatru. Bliskość ta bynajmniej nie jest przypadkowa; zdawali sobie z niej sprawę jezuiccy teologowie i właśnie w niej znajdowali argument dla aprobaty kultywowanej w ich środowisku praktyki.

Problemem w badaniu muzycznej warstwy jezuickich spektakli jest stan zachowania źródeł muzycznych. Do naszych czasów przetrwało zaledwie pięćdziesiąt partytur, pochodzących z jednego zaledwie kolegium w Wiednius. Liczniejsze są przekazy

4 Henry Schnitzler, „The Jesuit contribution to the theatre”, Educational Theatre Journal 4 (1952) nr 4, s. 283-292; William H. McCabe, Louis J. Oldani, An introduction to the Jesuit theater: a posthumous work, Saint Louis 1983 .

5 Waltraute Kramer, Die Musik im Wiener Jesuitendrama von I677-I7II. Inauguraldissertation zur Erlangung des Doktorgrades an der philosophischen Fakultät der Universität Wien, Wien 196I; Kurt Adel, Handschriften von Jesuitendramen in der Österreichischen National-Bibliothek in Wien, Wien 1960; Franz Hadamowsky, Das Theater in den Schulen der Societas Jesu in Wien (I555-I75I). Daten, Dramen, Darsteller. Eine Auswahl aus Quellen in der Österreichischen Nationalbibliothek, Wien-Köln I99I. 
librett tych przedstawień, które jednak utrwalano sporadycznie. Najwięcej zachowało się tzw. sumariuszy (gr. periochai), tj. streszczeń fabuły rozdawanych widzom. Z samych tylko krajów niemieckiego obszaru językowego pochodzi parę tysięcy tego typu źródeł; liczba przedstawień udokumentowanych w kronikach zakonnych jest jednak kilkukrotnie większa ${ }^{6}$. Dzięki obfitości takich przekazów jezuicki dramat był już wielokrotnie przedmiotem badań literaturoznawczych i teatrologicznych7 Źródła te coraz częściej jednak interesują także i muzykologów poszukujących w sumariuszach i librettach jezuickich dramatów szkolnych śladów obecności muzyki ${ }^{8}$. W przypadku niektórych spektakli można się nawet pokusić o rekonstrukcję ich warstwy muzycznej. Szczególnie wtedy, gdy równolegle zachowane są różne przekazy tych samych spektakli. Zestawienie ich ze sobą pozwala na odtworzenie metodyki kodowania w nich treści, odmiennej w różnych typach źródeł, w całości stanowiącej jednak dość logiczną strategię?

Sumariusze jezuickich spektakli stanowiły $\mathrm{w}$ gruncie rzeczy przekaz zaledwie komplementarny względem samego dramatu, należy więc je traktować jako źródła wobec tego gatunku pomocnicze i wtórne. $\mathrm{Na}$ ich podstawie możemy jednak zrekonstruować budowę niektórych spektakli, a także dowiedzieć się o muzycznych aspektach przedstawień, ujawnionych przede wszystkim tam, gdzie widz mógł potrzebować jakiegoś wyjaśniającego komentarza. Periochai mogły więc (choć wcale nie musiały) odnotowywać występowanie chórów, interludiów, tańców oraz innych scen spektaklu, którym towarzyszyła muzyka wokalna lub instrumentalna. W samej treści akcji pojawiały się także czasami wzmianki na temat muzycznego charakteru scen; odnotowane to było jednak tylko tam, gdzie muzyka stanowiła immanentny element omawianej w sumariuszu akcji. Ponadto, do niektórych programów dołączano imienne wykazy wykonawców wraz z podaniem pełnionej przez nich w przedstawieniu funkcji muzycznej.

Więcej informacji dostarczają libretta spektakli. Początkowo były one sporządzane w formie rękopiśmiennej; z czasem niektóre z nich także drukowano. Libretta dokumentują szczegółowy przebieg spektakli i odnotowują wskazówki wykonawcze,

6 Por. repozytoria tej bardzo bogatej literatury: Elida Maria Szarota, Das Jesuitendrama im deutschen Sprachgebiet: eine Periochen-Edition, München 1979; Jean-Marie Valentin, Le théâtre des Jésuites dans les pays de langue allemande. Répertoire bibliographique, Stuttgart 1983 (dalej jako: ValentinR).

7 Johannes Müller, Das Jesuitendrama in den Ländern deutscher Zunge vom Anfang (I555) bis zum Hochbarock (1665), Augsburg 1930; Kurt Adel, Das Wiener Jesuitentheater und die europäische Barock-dramatik, Wien 1960; Jean-Marie Valentin, Le théatre des Jésuites dans les pays de langue allemande (I554-I680); salut des âmes et ordre des cités, Bern-Frankfurt 1978.

8 Anna Mieczkowska, Muzyka w szkolnym teatrze jezuickim na terenie Rzeczypospolitej w XVII i XVIII wieku, Uniwersytet Warszawski 2006 (niepublikowana praca magisterska); Tomasz Jeż, „Między rappresentatione a melodrama sacrum. Muzyczne aspekty dramatu jezuickiego w barokowym Wrocławiu”, Muzyka 56 (20II) nr 3, s. 75-94; Anna Reglińska-Jemioł, Formy taneczne w polskim teatrze jezuickim XVIII wieku, Poznań 2012.

9 Tomasz Jeż, Kultura muzyczna jezuitów na Ślasku i ziemi kłodzkiej, Warszawa 2013, s. 312-378. 
określające formę gatunkową, obsadę oraz budowę poszczególnych elementów spektaklu. Czasami ich didaskalia informują o sposobie wykonania muzyki, sugerowanym do wykonania repertuarze, a nawet instrumentarium. Za szczególnego rodzaju źródła do badań nad muzyką jezuickich spektakli można jednak uznać także didaskalia dotyczące treści realizowanych za pomocą sztuk przedstawiających. Ze względu na „synestetyczny” profil poetyki tego gatunku, przedstawiane w nim treści często były obecne w analogicznych, równoległych dyskursach kilku dyscyplin sztuki, wzajemnie intensyfikując perswazyjność swego oddziaływania. Sposób tego oddziaływania w interesujący sposób ujawniają skorelowane ze sobą treści obrazowane równolegle w warstwach wizualnej i muzycznej jezuickiego dramatu szkolnego.

Za materiał porównawczy ilustrujący to zjawisko posłużą tu spektakle poświęcone tematowi misji, który dla jezuitów był zawsze bardzo istotny w dyskursie krzewionej przez nich kultury i akcentowany we wszystkich dziedzinach pielęgnowanej w ich kręgach sztuki. Sposoby przedstawienia tego tematu dość często odwołują się do emblematycznych ilustracji z druku Imago primi saeculi Societatis Ies $u^{\mathrm{IO}}$, którego

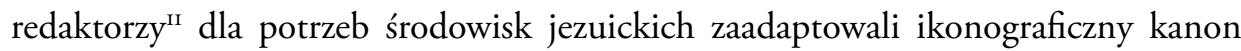
Cesarego Ripy ${ }^{12}$. Ryciny zamieszczone $w$ wydanym przez jezuitów druku na wiele lat zawładnęły wyobraźnią artystów działających w kręgach ich mecenatu i stały się wzorami dla podejmowanych $w$ ich pracach sposobów przedstawien ${ }^{13}$. Perswazyjne walory emblematyki z powodzeniem służyły nie tylko kultywowanym przez jezuitów sztukom przedstawiającym, lecz także dziedzinom twórczości spod znaku trivium, które wiązała ze sobą pragmatycznie stosowana ars rhetorica.

Dotyczyło to w szczególności jezuickiego teatru szkolnego, który w największym chyba stopniu oddany został na użytek prowadzonej przez ten zakon edukacji i propagandzie. Elementy te odnajdziemy także i w innych dziedzinach aktywności artystycznej, jednak to właśnie teatr, z racji swej społecznej roli, miał pod tym względem najbardziej istotne znaczenie. Zręczną symbiozę celów praktycznych i pragmatycznych można zresztą uznać za specyficzną cechę sztuki jezuickiej; ujawnia ją nawet jezuicka kartografia epoki (np. atlasy Heinricha Scherera ${ }^{\mathrm{I}}$ ), która umiejętnie wiąże zobiektywizowane dane geograficzne z treściami o charakterze społecznie perswazyjnym ${ }^{15}$. Jeśli koncypowana w ten sposób mapa jest „sposobem

Io Imago primi saeculi Societatis Iesu: a prouincia Flandro-Belgica eiusdem Societatis repraesentata, Antwerpen I640.

II Johannes Bolland, Philip Fruytiers, Cornelis Galle, Sidronius de Hossche, Jean de Tollenaere, Jacques van de Walle.

I2 Iconologia overo Descrittione dell'Imagini universali, Roma I593.

I3 Lydia Salviucci Insolera, L'Imago primi saeculi (I640) e ilsignificato dell'immagine allegorica nella Compagnia di Gesù: genesi e fortuna del libro, Roma 2004 (= Miscellanea historiae pontificiae 66), s. 5.

I4 Np. Geographia hierarchia sive Statvs ecclesiastici romano-catholici per orbem universum distributi succincta descriptio historico-geographica, Monachii 1703.

Is John Pickles, „Text, hermeneutics and propaganda maps”, w: Writing worlds: Discourse, text and metaphor in the representation of landscape, red. Trevor J. Barnes, James S. Duncan, London 1992, s. I93-230. 


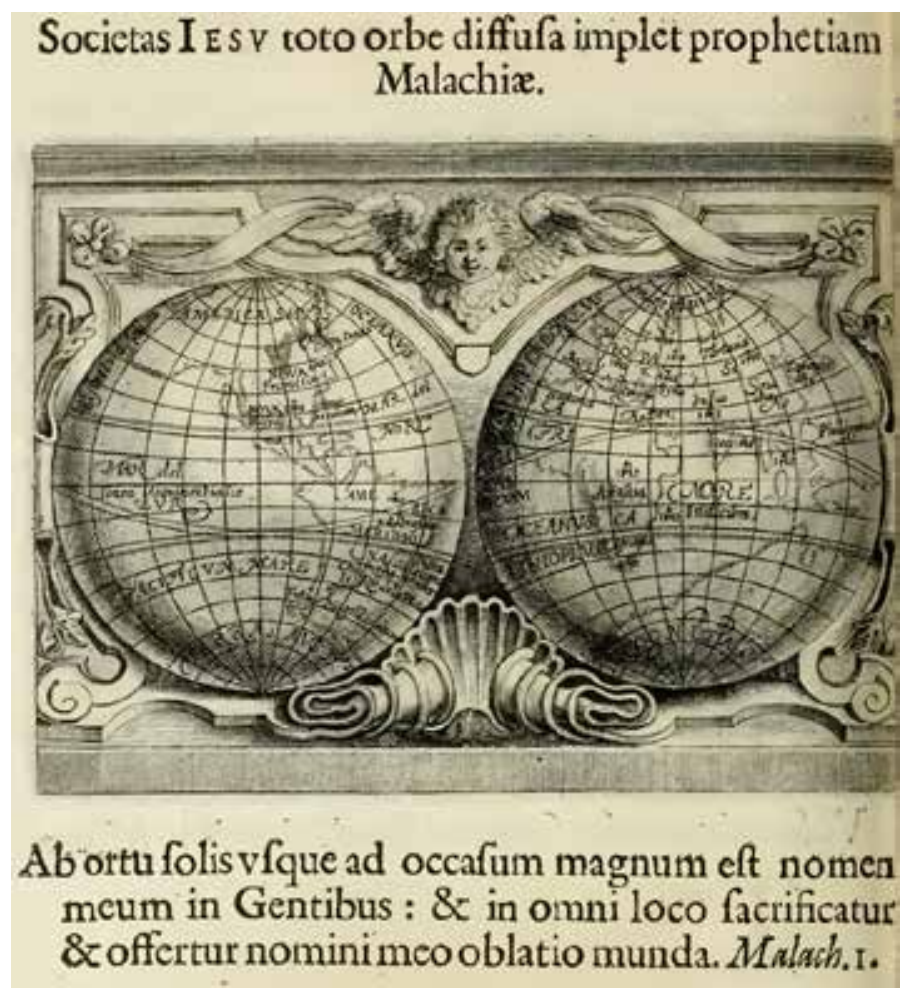

Il. I. Imago primi saeculi Societatis Iesu: a prouincia Flandro-Belgica eiusdem Societatis repraesentata [red. Johannes Bolland, Philip Fruytiers, Cornelis Galle, Sidronius de Hossche, Jean de Tollenaere, Jacques van de Walle], Antwerpen I640, s. 318.

na osiągnięcie ideologicznej dominacji nad przestrzenią" "', to są nim także takie przedstawienia artystyczne, które bazują na tym samym modelu emblematycznym. Wzorem Imago primi saeculi (il. I) przedstawiają one globalne rozprzestrzenianie się Słowa Bożego i wynikającą stąd powszechność kultu Imienia Boga, uzasadnianą przez fragment Ksiegi Malachiasza ${ }^{17}$ i korespondujący z nim werset Psalmu $I I 2^{18}$. Szczególnie ten drugi tekst cieszył się popularnością w przedstawieniach ikonograficznych jezuickich kościołów, m.in. we Wrocławiu ${ }^{19}$, ale także w twórczości muzycznej kompozytorów związanych z jezuitami w Rzymie, bardzo chętnie sięgających do tego tekstu biblijnego ${ }^{20}$.

I6 Bronisław Geremek, The common roots of Europe, Cambridge 1997, s. I58.

I7 „In omni loco sacrificatur et offertur nomini meo oblatio munda”, Ml I,II.

I8 „A solis ortu usque ad occasum laudabile nomen Domini”, Ps II2,3.

I9 Np. fresk Johanna M. Rottmayra na plafonie kościoła Najświętszego Imienia Jezus we Wrocławiu.

20 Giovanni Pierluigi da Palestrina, Hymni totius anni... quattuor vocibus concinendi, necnon hymni religionum, Roma 589 (RISM A/I: P 737); Agostino Agazzari, Musicum encomium, divini nominis, simplicibus, binis, ternis, quinisque vocibus..., Roma I640 (RISM A/I: A 379). 


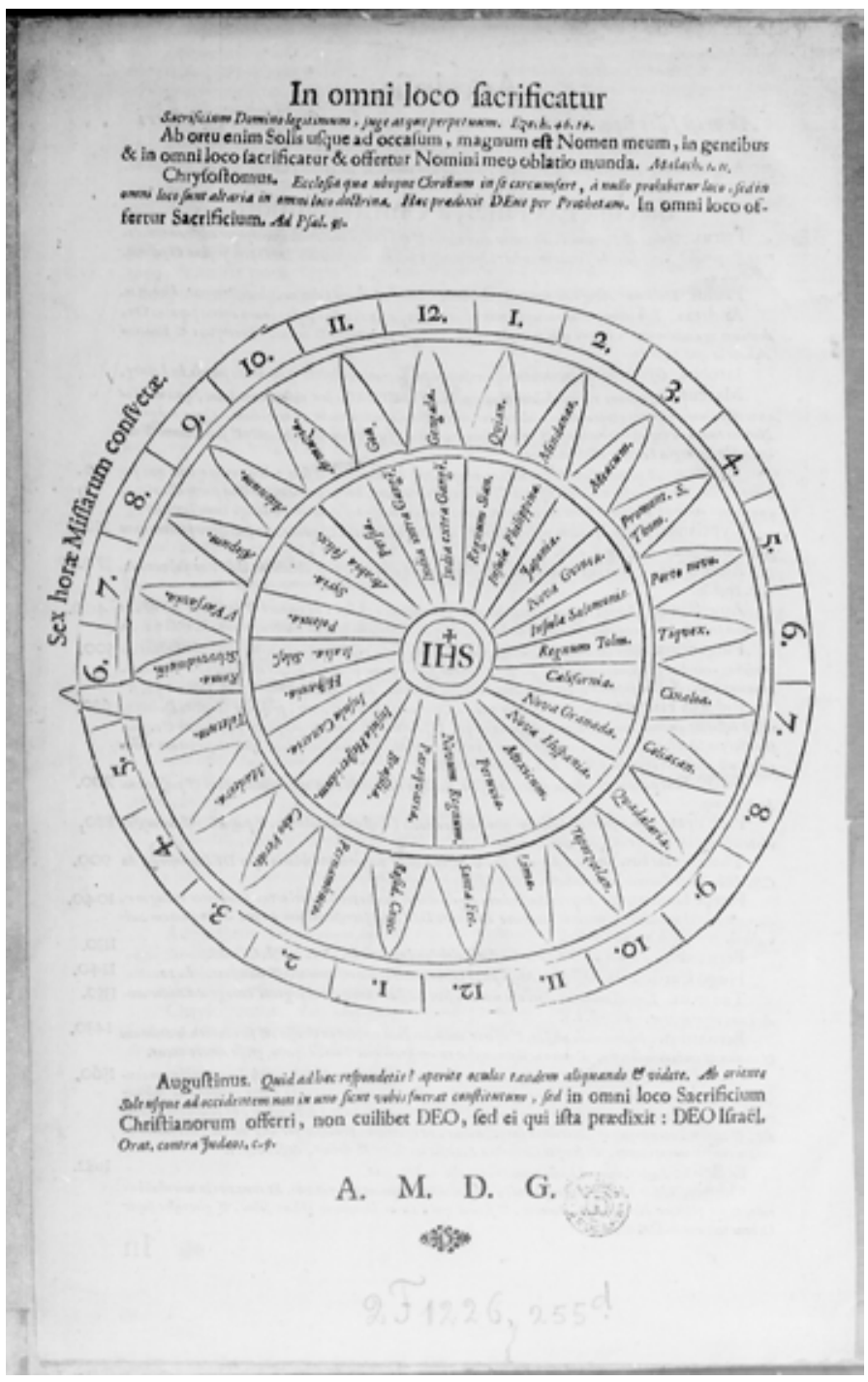

Il. 2. Inge sacrificium in figuris praesignatum praecipue in Melchisedech..., Wrocław 1682. Wrocław, Biblioteka Uniwersytecka, Oddział Starych Druków, sygn. 369.500.

Dokładnie ten sam topos odnajdujemy również w sumariuszu spektaklu teatralnego, wystawionego w I682 r. w Świdnicy (il. 2). Przedstawienie to wieńczyła emblematyczna pegma z cytatem przytoczonego wyżej wersetu psalmowego. Tekst perioche spektaklu kończy zaś unikatowe przedstawienie ikonograficzne (w jakiś zapewne sposób odnoszące się do treści ukazywanych na scenie), które obrazuje globalny charakter kultu eucharystycznego, dzięki jezuickim misjom sprawowanego bez przerwy we wszystkich strefach czasowych globu. Przedstawienie to również nawiązuje do 


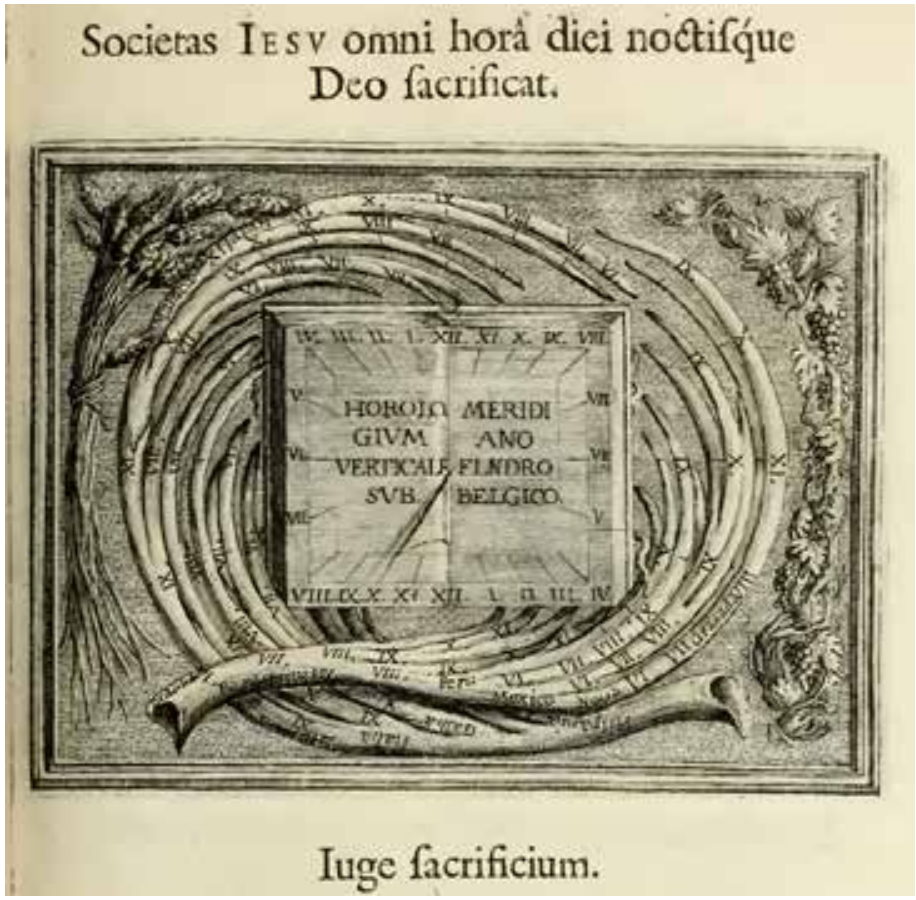

Il. 3. Imago primi saeculi Societatis Iesu..., op. cit., s. 319 .

ryciny zaczerpniętej z Imago primi saeculi (il. 3), co potwierdza zapożyczony stamtąd tytuł całej sztuki. Wprawdzie z przekazu sumariusza nie wiemy, czy finałowej scenie tego spektaklu towarzyszyła muzyka (wykonywana często w tego typu miejscach); wiadomo jednak, że komponowano w tym czasie wiele utworów muzycznych, które nawiązywały do tej tematyki.

Przykładem tego jest choćby koncert działającego m.in. w Świdnicy ${ }^{21}$ Georga Brauna SJ pt. In nomine Jesü ${ }^{22}$, którego słowa parafrazują popularny w środowisku jezuickim werset Pawłowego Listu do Filipian ${ }^{23}$. Tekst ten, szeroko eksploatowany w promowanym przez jezuitów kulcie Imienia Jezus, został tu tropowany słowami, które nawiązują do toposu „a solis ortu usque ad occasum” ${ }^{24}$. Słowa tropu odwołują

2I Hermann Hoffmann, Die Jesuiten in Schweidnitz, Schweidnitz 1930 (= Zur schlesischen Kirchengeschichte 3), s. 207.

22 PL-Wu RM 6084. Por.: Georgius Braun (I658-I709). In nomine Jesu, O caelitum Dux, wyd. Tomasz Jeż,

Warszawa 2017 (= Fontes Musicae in Polonia, C/II).

23 „In nomine Jesu omne genu flectatur, coelestium, terrestrium et infernorum”, Flp 2,Io.

24 Georgius Braun, In nomine Jesu:

„A te lux speciosa, gentium fax

a te lex gratiosa, mentium pax.

A te luce clarescit oriens

ista flamma calescit occidens". 


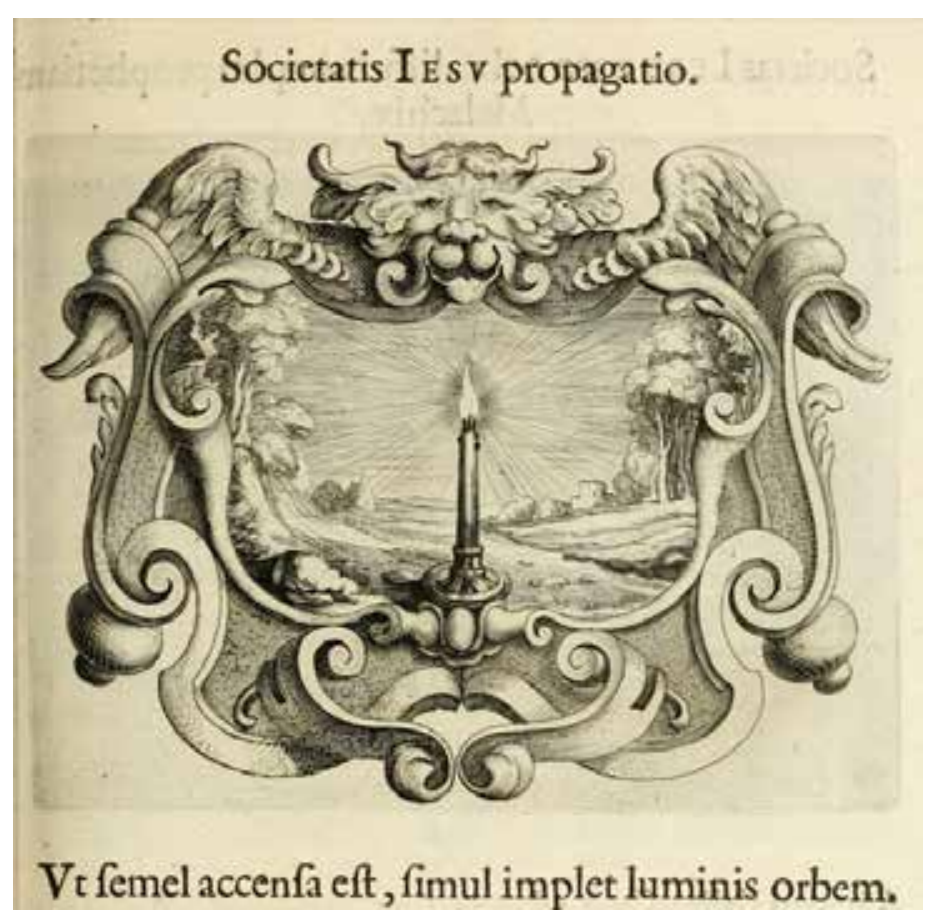

Il. 4. Imago primi saeculi Societatis Iesu..., op. cit., s. 3 I7.

się także do kolejnego przedstawienia z Imago primi saeculi (il. 4), którego treścią jest topos szerzącego się po całym świecie Chrystusowego światła. Odnajdujemy go też we freskach Andrei Pozza, choćby tych z rzymskiego kościoła Sant'Ignazio ${ }^{25}$. Głównym bohaterem tego przedstawienia jest jednak nie tyle Boskie światło, co szerzący je Ignacy Loyola, ukazany tu w konwencji apoteozy. W bardzo podobnej retoryce święty ten przedstawiony został - wraz ze swoim towarzyszem Franciszkiem Ksawerym - w spektaklu teatralnym Apotheosis sive consecratio SS. Ignatii et Francisci Xaverii, wystawionym przy okazji kanonizacji obydwu jezuitów w roku I622 w sąsiadującym z kościołem Sant'Ignazio Collegium Romanum.

Zachowana do naszych czasów muzyka do tego spektaklu autorstwa Johannesa Hieronyma Kapsbergera ${ }^{26}$ jest doskonałym przykładem tego, jak mogła wyglądać

25 Andrea Pozzo, Apoteoza św. Ignacego Loyoli, Rzym, kościół św. Ignacego.

26 Wien, Österreichische Nationalbibliothek (dalej jako A-Wn), Musiksammlung, sygn. Mus.Hs.I6or3. Kompozycja ta była już przedmiotem zainteresowania muzykologów, zob. m.in.: James Forbes, The nonliturgical vocal music of Johannes Hieronymous Kapsberger (I580-I65I), University of North Carolina I977 (niepubl. dysertacja), s. 27I-44I; Emilio Sala, Federico Marincola, „La musica nei drammi gesuitici: il caso dell' Apotheosis sive consecratio sanctorum Ignatii et Francisci Xaverii (1622)”, w: I gesuiti e i primordi del teatro barocco in Europa, red. Maria Chiabò, Federico Doglio, Roma 1994, s. 389-440; Thomas Frank Kennedy, Jesuits and music. The European tradition, 1547-1622, University of California I982 (niepubl. dysertacja), s. 200-210. 


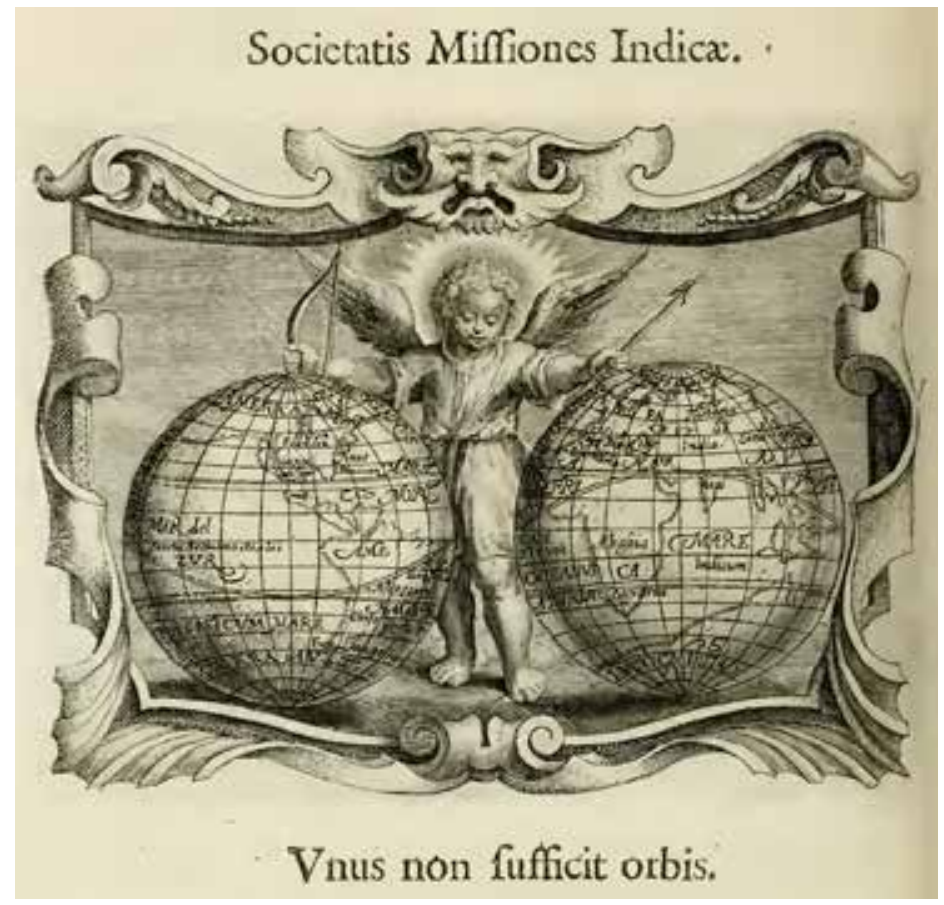

Il. 5. Imago primi saeculi Societatis Iesu..., op. cit., s. 326.

muzyczna warstwa jezuickich spektakli teatralnych, nawet jeśli uznamy, że akurat to dzieło było pod tym względem wyjątkowo bogate. Spektakl ten jest w całości przekomponowany muzycznie; kolejne akty składają się z rozbudowanych sekwencji arii, recytatywów, chórów, ritornellów i tańców. Spośród wielu scen tego przedstawienia na uwagę zasługuje w badanym tu kontekście m.in. ta pierwsza, w której Roma poleca w jednym z recytatywów Metagenesowi, by ten skonstruował pomnik dedykowany czci Ignacego Loyoli i kanonizowanemu przy tej samej okazji Franciszkowi Ksaweremu:

Sacra coelo dum surgit strues

Iterate cantum puberes, Magnum Patrem

Similemque: Natum in vota jam pronos mea.

Ab orbe gemino carmen invitet sacrum.

Te „bliźniacze kręgi” to dwie półkule naszego globu ${ }^{27}$, często przedstawiane w tej właśnie formie graficznej, znanej nie tylko ze wzmiankowanego wyżej jezuickiego podręcznika (il. 5). Bliźniactwo Wschodu i Zachodu, Ignacego i Franciszka

27 J. Forbes, op. cit., s. 299. 
(chrześcijańskich Kastora i Polluksa ${ }^{28}$ ), symbolizujących obydwu świętych żywiołów ognia i wody oraz zestawianych kolejno par alegorycznych postaci określa zresztą cały retoryczny koncept spektaklu.

Pierwszy akt tego przedstawienia należy do Hiszpanii i Portugalii - krajów, które zgodnie z traktatem w Tordesillas w I494 r. podzieliły między siebie glob na dwie półkule; przy okazji apoteozy obydwu świętych jezuickich kraje te składają im dary: broń używaną w młodości przez Ignacego i statek, którym Franciszek dopłynął do Indii. Darom składanym świętym przez Indie (perły) i Palestynę (kadzidło) towarzyszy taniec przedstawicieli obydwu tych krain, którego układ choreograficzny wedle zachowanego libretta miał reprezentować glob ziemski, utworzony z sześciu łuków ${ }^{29}$. Przedstawienie to chyba nieprzypadkowo kojarzy się z przytoczoną wyżej ryciną z Imago primi saeculi, ukazującą anioła (geniusza misji) opiekującego się jezuickimi misjami na obu półkulach globu, w którego ręku widoczne są właśnie łuk i strzały.

Muzyczna charakterystyka poszczególnych postaci alegorycznych nie wykazuje żadnych związków z rzeczywistymi miejscami ich pochodzenia; odróżnia je jednak konsekwentnie stosowany przez kompozytora sposób kształtowania linii melodycznej i charakterystycznych zwrotów kadencyjnych ${ }^{30}$. Tańce towarzyszące kolejnym scenom to gagliardy, villanelle i moreski; również pozostałe wykorzystane tu gatunki muzyczne - arie, recytatywy i chóry - nawiązują do konwencjonalnych wzorców. Nie wiemy, jak wyglądała muzyczna warstwa spektakli wystawianych na wzór Apotheosis Kapsbergera w innych ośrodkach Europy ${ }^{31}$, cechowal je jednak podobny koncept retoryczny o treści alegorycznej. W perioche spektaklu wystawionego w tym samym roku w Ingolstadt ${ }^{22}$ pojawiają się teksty biblijne poddawane częstokroć umuzycznieniu („Sanctus, sanctus, sanctus, Dominus Deus omnipotens”; „Benedictio et claritas et sapientia, et gratiarum actio”),

Novus Castor et Pollux Ignatius Loyola Franciscus Xaverius genuini, et germani e Societate Jesu fratres, Cor unum, et anima una, Toti Orbi Salutares, Relati inter sidera..., Praha I674.

29 Dołączone do partytury wiedeńskiego rękopisu spektaklu Argomento dell'Apoteose o Consagrazione dei Santi Ignazio Lojola e Francesco Saverio Rappresentata nel Collegio Romano nelle feste della lo Canonizzazione l'Anno I622, następująco opisuje tę scenę (fol. 3Iv): „...poi gl'Indiani con gli archi loro formano al Saverio un nuovo mondo, e di cosa mirabile come con sei archi si formi un globo tutto intero, nel quale sono dipinte tutte le parti della terra, e ciò in un batter d'occhio, imperciochè era ogni arco doppio, e composto in maniera, che racchiudeva in se piegata la sesta parte del globo” („[...] następnie Indianie formują za pomocą swoich łuków dla Ksawerego nowy świat, utworzony w tak wspaniały sposób, że sześć łuków układa się na glob cały, na nim zaś narysowane są wszystkie kontynenty. W mgnieniu oka okazuje się jednak, że każdy z tych łuków był podwójny i po rozdzieleniu tworzą one obie ziemskie półkule”).

30 J. Forbes, op. cit., s. 313-343.

3I Servus Abrahami Rebeccam Isaaco ex Mesopotamia deducens seu Franciscus Xaveris Sponsam Christi ex India magno labore adducens..., Ingolstadt 1622 (ValentinR 660); Franciscus Xaverius..., Fribourg en Brisgau, I622 (ValentinR 882).

32 Triumph des heiligen Ignatius und des heiligen Franz Xaver..., Ingolstadt I622 (ValentinR 885). 
co może sugerować, że w ramach spektaklu wykonywano utwory o tych właśnie incipitach słownych.

W rocznicę kanonizacji Franciszka Ksawerego uczniowie Collegium Romanum wystawili na jego cześć spektakl Pirimalo Tragedia, który zapoczątkował całą serię przedstawień wyprawy na Wschód jezuickiego misjonarza ${ }^{33}$. Ów pierwszy dramat opowiadał historię nawrócenia przezeń Pirimala, księcia Cejlonu, którego następstwem była jego męczeńska śmierć poniesiona z ręki Turimbala, tyrana Malakki. Wskazanymi w perioche elementami muzycznymi spektaklu były umieszczone wewnątrz aktów sceny taneczne: hałaśliwy taniec hinduskich braminów (akt I, scena 3) i radosne pląsy Franciszka Ksawerego, który odnalazł na brzegu morskim zagubiony podczas podróży morskiej krucyfiks (IV/4). Występują tu także liczne sceny muzyczne, kontrastujące wątki o konotacji negatywnej (IV/2: dumny dwór króla Malakki) z tymi pozytywnymi (IV/3: śpiew hinduskich neofitów ku czci jezuickiego misjonarza). Ogólną kompozycję spektaklu porządkuje koncept konfrontacji cywilizacji, osiągający swe apogeum w ostatniej scenie bitwy morskiej między „Barbares” a „Lusitanes”. Konflikt pogańskiego świata Indii z cywilizacją chrześcijańskiej Europy kończy się wprawdzie śmiercią pierwszego hinduskiego męczennika; jest on jednak przedstawiany jako triumf Kościoła i zaczyn ewangelizacji całego kontynentu.

Uzasadnienie dziejowej konieczności chrystianizacji Wschodu przynosi kolejny spektakl o podobnej treści, wystawiony w Wiedniu z okazji jubileuszu stulecia istnienia Towarzystwa Jezusowego ${ }^{34}$ i powtórzony tamże kilkanaście lat później35. Zachowane sumariusze obydwu spektakli są mało informatywne dla rekonstrukcji warstwy muzycznej. Krótkiego komentarza jednak wymaga opracowana przez $\mathrm{Ni}$ colausa Avanciniego treść literacka samego dramatu. Franciszek Ksawery przedstawiany tu jest jako światło prawdziwej wiary, zwyciężające mroki dalekowschodniej idolatrii. Za blaskiem prawdy chrześcijaństwa tęskni Orient, któremu podległe są cztery królestwa; jego pragnienia są zresztą także personifikowane jako „Desideria Orientis" (ich liczba chyba nieprzypadkowo zgadza się z liczbą pięciu zmysłów). Większość akcji dzieje się w Europie, dokąd docierają westchnienia Orientu i budzą misyjny zapał jezuity, który musi być jednak przed wysłaniem na misje pomyślnie zweryfikowany próbą charakteru. Gdy w końcu misjonarz dociera do Indii, poleca katechizowanym przez siebie dzieciom usunąć obrazy idoli ze ścian swych domów, za co spotyka je prześladowanie ze strony rodziców. Cała treść spektaklu

33 Bruna Filippi, Il teatro degli argomenti: gli scenari seicenteschi del teatro gesuitico romano: catalogo analitico, Roma 200I (= Bibliotheca Instituti Historici S.I. 54), s. IO4-II2.

34 Zelus sive Franciscus Xaverius Indiarum Apostolus..., 1640 (ValentinR I285). Zob. Martina Egger, Nikolaus von Avancini S.J., die Theologie eines Jesuitendramatikers, Leopold-Franzens-Universität 2000 (niepubl. dysertacja), s. 49.

35 Zelus Ignatianus a divini nominis et gloriae zelo accensus..., I65I. A-Wn, Sammlung von Handschriften und alten Drucken, Cod. I3258 Han. (ValentinR I619). 


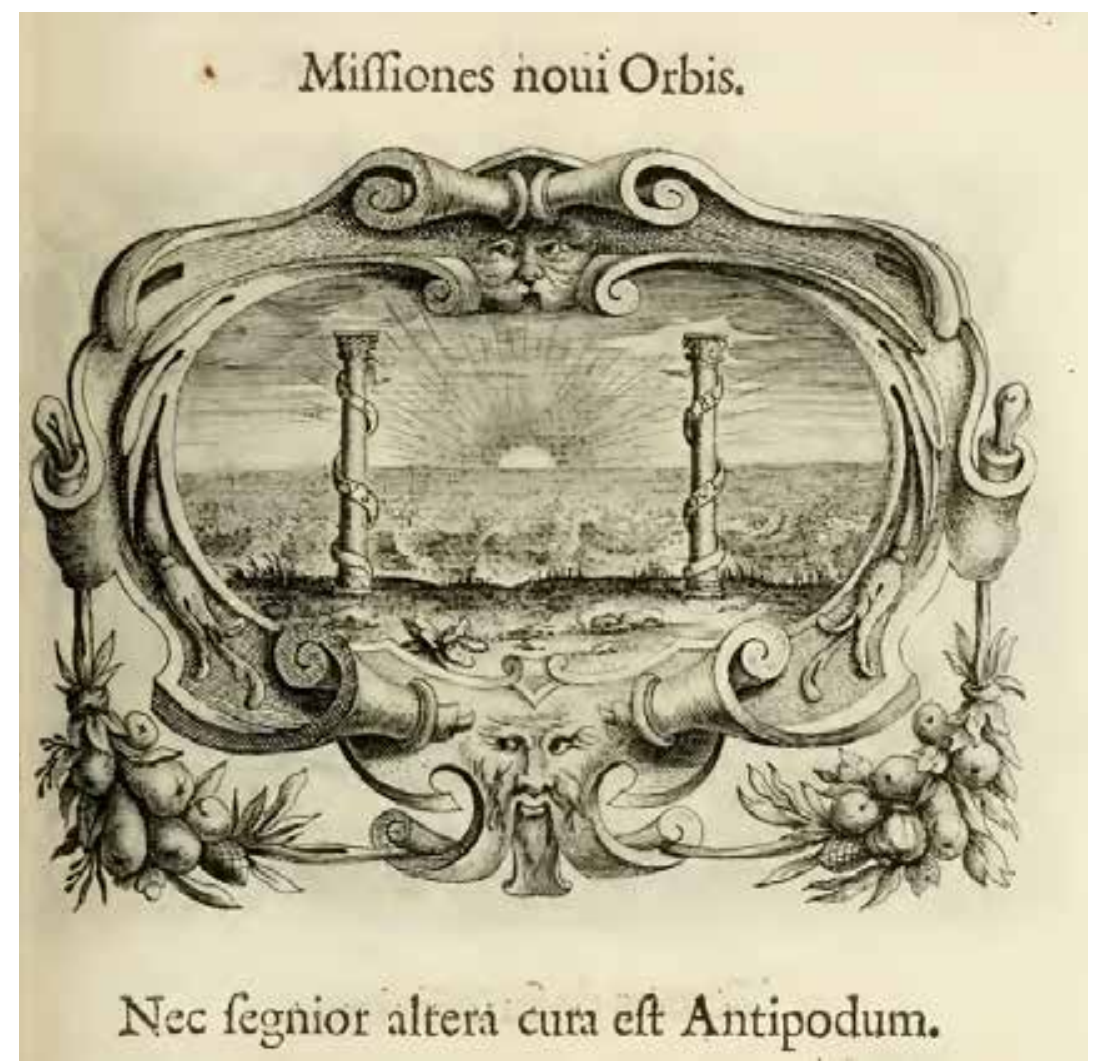

Il. 6. Imago primi saeculi Societatis Iesu..., op. cit., s. 327.

i jego wydźwięk ideowy podporządkowane są więc wyraźnie celom dydaktycznym i wychowawczym.

Franciszek Ksawery w wielu dramatach przedstawiany jest zresztą za pomocą metafory „nowego słońca Orientu”, przychodzącego paradoksalnie z Zachodu na Wschód ${ }^{36}$. Przedstawienie tego rodzaju - mające również swoją ikonograficzną dokumentację - wywodzi się najprawdopodobniej z jeszcze jednej ryciny Imago primi saeculi, przedstawiającej słońce wschodzące po zachodniej stronie Oceanu Atlantyckiego, widziane z perspektywy słupów Herkulesa (il. 6). Do Herkulesa przyrównywany jest zresztą i sam Franciszek Ksawery, na przykład w spektaklu pochodzącym $\mathrm{z}$ Egeru, zachowanym w postaci obszernego rękopiśmiennego

36 Epitome Dramatis quo D. Franciscum Xaverium pro Temporalibus Aeterna reddentem Societati Iesu gratitunis causa in publico \& Academico Antiquissimae \& Celeberrimae Viennensis Universitatis Theatro Exhibuit..., Wien 1651; Triumphus D. Francisci Xaverii..., Luzern 1654; Amplius Labor et Dolor. Psal. 89. Sive Crucis Amor S. Francisci Xaverii a Patientia probatus et praemiatus..., Olomouc I658. 
libretta $^{37}$. Opatrzone ono zostało licznymi didaskaliami i towarzyszącymi każdej scenie epigramatycznymi lemmata, odnoszącymi prezentowaną scenicznie treść do adekwatnych wersetów biblijnych. Jak wiemy z analogicznych przekazów, scenom tego rodzaju towarzyszyła zazwyczaj muzyka instrumentalna, która pogłębiała i intensyfikowała treść przedstawioną za pomocą ozdobnego napisu ${ }^{38}$. Dramat przedstawia alegoryzowaną historię życia Franciszka, odbywającego w kolejnych pięciu aktach misję po kolejnych pięciu krainach Orientu: Etiopii, Indiach, Japonii, Chinach i Goa. W trakcie spektaklu pojawia się wiele scen stricte muzycznych, w różny sposób odnoszących się do akcji dramatu. Akt I wieńczy Chorus Ludicro-Serius: upijający się winem z lotosu Hindusi umilają sobie czas grą na cytrze. Pojawiająca się w trakcie aktu II „Scena Muta Ethico-Ludicra sive Mimica” to z kolei pantomima przedstawiająca ciemnoskórego Cygana Burdo, który bezskutecznie usiłuje zmienić kolor swojej skóry. Jak wiemy z analogicznych przekazów, scenom niemym towarzyszyła zazwyczaj epigramatyczna lemma i muzyka instrumentalna, która pogłębiała i intensyfikowała przedstawioną scenicznie treść.

Dwie pierwsze sceny utrzymane są w konwencji karykatury i ukazują kultury pozaeuropejskie w krzywym zwierciadle; kolejne dwie sięgają jednak konwencji seria: akt II wieńczy chór syren i trytonów śpiewających hymn ku czci jezuickiego misjonarza, przekraczającego właśnie w swym statku Zwrotnik Raka, akt III zaś urozmaica chór „Pauperes in Japonia Mulieribus”, które za sprawą Franciszka Ksawerego przyjęły chrześcijaństwo; skutkiem tej decyzji było odrzucenie przez ich mężów, trwających uparcie w ślepocie idolatrii. W połowie aktu IV powraca konwencja buffa muzycznych interludiów: w alegorycznej scenie Apollon i Amfion prowadzą muzyczny pojedynek, zmagając się w sztuce gry na różnych instrumentach muzycznych. $Z$ tą dość zabawnie ukazaną sceną kontrastuje chór wieńczący akt IV spektaklu - lament Geniusza Nawarry, opłakującego śmierć misjonarza. Radosny nastrój wróci dopiero w scenie V/4, w której Portugalczycy śpiewają razem z Hindusami hymn tryumfu świętego. Do ich chóru dołączają się także Japończycy i Chińczycy, a całość sceny kończy taniec personifikowanej Nieśmiertelności i finatowa ansamblowa licenza.

Obrazowanie świata Dalekiego Wschodu jako krain ciemności pod panowaniem idolatrii stało się normą w większości późniejszych przedstawień, które różnicowała jedynie dyspozycja akcentów i przyjęty przez autora spektaklu koncept. Franciszek Ksawery przedstawiany bywał jako nowy Herkules ${ }^{39}$, słońce

Nox orientis per solem Hesperium Franciscum Magnum Cognomento Xaverium Sacrae Romanae Ecclesiae nuncium apostolicum discussa..., Amberg 1658. Rękopis znajduje się w Pradze, Strahovská Knihovna, sygn. 9138 / D E IV I3.

38 H. Schnitzler, op. cit., s. 286.

39 Hercules Asiaticus. D. Xaverius Decennalibus in Oriente laboribus gloriosus..., Praha I667. 
Indii ${ }^{40}$, wysłannik pokoju i nadzieja Wschodu ${ }^{41}$. Jednoznaczność wniosków, które mogły być wyciągnięte przez widzów tych przedstawień, czasami łagodziło zaszyfrowanie tożsamości postaci spektaklu przez nadanie im imion symbolicznych ${ }^{42}$. Innym razem przekazywaną w dramacie treść ideową ukrywano w jego konceptualnej konstrukcji, przedstawiającej np. spór między Nawarrą, Indiami, Italią i Austrią, dotyczący tego, gdzie święty Franciszek czczony jest najbardziej ${ }^{43}$. Spektakl ten jest zresztą rzadkim przykładem w całości przekomponowanej muzycznie formy, która składa się ze śpiewanego prologu, pięciu scen obejmujących parę recytatywu i arii oraz finałowego chóru. Piątą scenę spektaklu przedstawia Anima Christiana, wezwana przez cztery krainy świata do internalizacji poruszanych treści; przeszkadza jej w tym nieco Idololatria, pomagają zaś Pietas i Fides.

Wśród wielu innych spektakli dedykowanych czci pierwszego jezuickiego misjona$\mathrm{rza}^{44}$ na uwagę zasługuje jeszcze jedno przedstawienie udokumentowane w formie dru-

40 Sol in India Orientali olim Gloriosa Morte occidus in novis Indiis. Oriens inoccidus Sanctus Franciscus Xaverius Ambiguae Juventuti ab eo Qui Solem suum oriri facit super bonos \& malos (Mt 5,45) pro eligenda via Salutis in lucem er ducem Coelitus datus..., Praha I740.

4I Signifer magni ducis D. Franciscus Xaverius, cuius industria, atque indefesso labore signum pacis inter Gentes Orientales erexit Divina Providentia..., Praha 1669.

42 Laureola Martyrij D. Francisci Xaverij In Symbolica Daphniphori Corona adumbrata..., Praha I66r: Agenoris = Europa

Areogenus = Mars Indicus

Afebaeus = Idololatria

Daphniphorus $=$ S. Xaverius

Japetias = Asia

Omosophus $=$ Crudelitas

Patrianophilus $=$ Religio vera

Philotheus $=$ Amor

Philoictus $=$ Commiseratio

Philosterius $=$ Zelus

Philoponos = Amor Laborum

Proles caeca $=$ Populus Indiae.

43 Geistlicher Streitt Etlicher Königreich und Länder wegen Verehrung deß grossen Indianer Apostels Deß Heil. Francisci Xaverii Auß der Gesellschaft Jesu..., Graz 1715 (ValentinR 4006).

44 S. Franciscus Xaverius admirabilis..., Olomouc I661; Franciscus Xaverius..., Straubing 1654 (ValentinR 2060); Jucundus homo Petrus Vellius Latrunculis ludens S. Francisci Xaverii interventione..., Jihlava 1667; Franciscus Xaverius tempore studiorum Parisijs..., Emmerich I668 (ValentinR 2169); Xaverianum sospirium..., Innsbruck 1672 (ValentinR 2320); S. Xaverius Indicus Apostolus..., Landsberg 1675 (ValentinR 2428); S. Franciscus Xaverius..., Landsberg 1675 (ValentinR 2459); De S. Francisco Xaverio..., Wien 1676 (ValentinR 2470); S. Franciscus Xaverius..., Luzern 1677 (ValentinR 2494); Opus posthumum Sancti Francisci Xaverii..., Prag 1677; S. Franciscus Xaverius..., Ingolstadt I684 (ValentinR 274I); Animae Xaverianae Amantis Affectus..., Ellwangen I69I (ValentinR 30II); Adolescentia Salomonis seu connubium Reginae Sapientiae cum Salomone adolescende... S. Francisco Xaverio..., Paderborn 1693 (ValentinR 3083); S. Franciscus Xaverius..., Aix-la-Chapelle I709 (ValentinR 3760); Pulchri super montes pedes Annunciantis, et Praedicantis pacem..., Praha I7ı; S. Franciscus Xaverius moriens..., München I724 (ValentinR 4422); S. Franciscus Xaverius Deliberans Tempore verni Jenunii..., Straubing 1730 (ValentinR 4775); S. Xaverius..., Köln 1734 (ValentinR 4956); Xaverius..., Emmerich 1735 (ValentinR 5034); Heldenmuth Francisci Xaverii..., Graz 1738 (ValentinR 5226); Heylsamer Frucht Durch Mariae Virbitt aus denen Geistlichen Ubungen des Hl. Ignatii und Xaverio..., Regensburg 1742 (ValentinR 5556); 
kowanego libretta ${ }^{45}$. Spektakl ten był w znacznej swej części wykonywany muzycznie ${ }^{46}$, o czym świadczą podane w treści źródła określenia partii wokalnych (Canto, Alto, Tenore, Basso, Solo, Tutti), nazw gatunkowych (Recitativo, Aria, Duetto, Chorus da Capo) oraz określeń scen muzycznych (Musikalische Vorspiel, Saltus). Występujące w trakcie akcji tańce skonstrastowane są pod względem semantycznym - akt I rozpoczyna alegoryczny Helden czyli „Tantz in welchem der grosse Eiffer Xaverii so beyde Welt will umbfangen, erweisen wird”; akt II - „Tantz wilder und unglaubiger Völker so mit Waffen auff Xaverii Schirmengel los gehen”; akt III - „Saltus Furiarum”; w połowie aktu IV pojawia się „Saltatus Virtutum”; a w akcie V aż dwie sceny taneczne - „Saltus Sagittariorum” i „Saltatus Xaverii sub Aethiope vacillantis”. Konceptualne przeciwstawienie biegunowo różnych pod względem charakteru scen tanecznych relatywizuje jednak treść interludiów: jest nią „Mors Lutheri opposita morti Xaverii”, stanowiąca kolejny komiczny kontrapunkt do przedstawianej w głównym dramacie historii śmierci Franciszka Ksawerego. Intermedia te opowiadają o ostatnich dniach życia Marcina Lutra i również wyposażone są w warstwę muzyczną, obfitującą w sceny taneczne i pieśni.

Muzyczne obrazowanie treści reprezentowanych wizualnie potwierdzają nielicznie zachowane kompletne zestawy źródeł jezuickiego dramatu. Te pochodzące z wiedeńskiego kolegium przekazy obejmują w kilkudziesięciu przypadkach jednocześnie perioche, libretto i partyturę muzyczną. Dopiero na podstawie wszystkich trzech form utrwalenia dzieła sceniczno-muzycznego jesteśmy w stanie dokonać nieco bardziej wiarygodnej jego rekonstrukcji. Porównanie trzech równoległych przekazów pozwala także na przekonujące wnioski dotyczące charakteru każdego z tych źródeł i stosowanych w nich konwencji określających sposób redukcji treści.

Za przykład niech tu posłużą takie właśnie komplementarne względem siebie źródła dramatu Ferdinandus quintus rex Hispaniae Maurorum domitor, do którego muzykę skomponował Johann Bernhard Staudt ${ }^{47}$. W drukowanej perioche tego spektaklu zachodzące na scenie zdarzenia relacjonowane są jedynie w formie ogólnikowego streszczenia. W dołączonym do tego druku libretcie mamy już pełen tekst dziejącej się na scenie akcji, zaś w partyturze - muzyczne jego opracowanie, rozdysponowane między arie, duety, recytatywy i ansamble. Dzięki porównaniu analogicznych przekazów źródłowych widać, że scena określona w perioche po prostu jako chorus mogła być w istocie kilkunastoodcinkową sekwencją arii, recytatywów, duetów, ansamblów i muzyki instrumentalnej, tworzącą muzycznie

Sanctus Franciscis Xaverius..., Dillingen 1753 (ValentinR 6392); Francisus Xaverius..., Emmerich 1768 (ValentinR 7397).

45 S. Xaverius apud Sinas moriens tragoedia..., Köln 1724.

46 Jak podaje libretto, „Die Music hat componiert der Herr Ignatius Liechtenauer Capellen-Meister in der Thumb=Kirchen zu Osnabrück".

47 A-Wn, Musiksammlung, Mus.Hs. Cod. 18875 Leopoldina. Zob.: Ferdinandus Quintus Rex Hispaniae Maurorum Domitor. Drama des Wiener Jesuitenkollegs anläßlich der Befreiung von der Türken I683, red. Walter Pass, Graz 198I (= Denkmäler der Tonkunst in Österreich I32). 
przekomponowaną całość ${ }^{4}$. Zjawisko takie spotykamy również w niektórych scenach tego dramatu, np. w tej, która alegorycznie przedstawia zwycięstwo świata chrześcijańskiego (reprezentowanego tu przez Słońce) nad muzułmańskim (Księżyc) ${ }^{49}$, temat bardzo chętnie podejmowany w ikonografii po Wiktorii Wiedeńskiej roku I683: zarówno w postaci personifikowanych alegorii Religii i Herezji, jak i symbolizujących je ciał niebieskich. W omawianym dramacie Sol Laetitiae jest zresztą jedną z ważniejszych postaci.

Wieloodcinkowe sceny o charakterze stricte muzycznym odnajdujemy także w treści głównej dramatów umuzycznionych przez Staudta: obejmują one zazwyczaj całości nieco krótsze niż te umieszczone w wyżej omówionych chórach; są najczęściej kilkuodcinkowe i komplementarne wobec deklamowanych fragmentów libretta. Przykładem tego jest np. odcinek znajdujący się między sceną 2. a 3. aktu III dramatu Ferdinandus quintus rex Hispaniae, kiedy to Boabdilowi śni się rozmowa jego Anioła Stróża z Geniuszem Hiszpanii; jej konkluzja skłania mauretańskiego władcę po obudzeniu się z tego snu do działania. Jest ono jednak bezskuteczne wobec koalicji wojsk chrześcijańskich, które po pokonaniu Maurów śpiewają w Epilogu panegiryczną ansamblową licenzę ${ }^{\circ}$. Jej adresatem jest „Domus Austriaca contra Barbaros triumphantem", na widowni spektaklu uosabiana przez samego cesarza Leopolda I Habsburga, który z pomocą sojuszników (nie wymienionych tu co prawda ani z imienia, ani z przynależności państwowej...) pokonał pod Wiedniem wojska Kara Mustafy.

48 Ferdinandus Quintus, Akt I, Chorus:

I3. Sonata

I4. Genius Hispaniae: „O cellum orbis et prolem lucis”

I5. Consilium, Industria: „Quae tormenta mantem vellicant”

I6. Mars: „Volamus ad bella, duella!”

17. Industria, Consilium: „Labantem stipate”

I8. Mars: „Labantem stipamus novisque triumphus”

I9. Industria, Pietas: „Quae nova lux, que mira crux effulget in leone?”

20. Industria: „Io! Io! Iberia, triumphas!”

2I. Consilium: „Regum gemma”

22. Genius Hispaniae: „Hac laeta spe amante caelo me triumpho”

23. Mars: „Iam hostis ausus et sistam plausus”

24. Genius Hispaniae, Industria, Consilium: „Ut tela iactat sic invocantes”

25. Ritornello.

49 Ferdinandus Quintus, Akt II, scena 4:

26. Luna: „Iam princeps una per astra luna”

27. Sol: „Ambitiosa! Phoebo exosa!”

28. Genius Hispaniae, Confoederatio: „Non splendebis, non eminebis”

29. Luna: „Mirabo et luce plenas faces vibrabo”

30. Imperium, Confoederatio: „Atrore conderis”

3r. Luna: „Heu! Liquor numer surripitur lumen!”

32. Sol: „Iam tabescis, tenebrescis!”.

so Biorą w niej udział: Genii Austriae, Hungariae, Bohemiae, Styriae, Tyrolis, Carinthiae, Carnioliae, Poloniae, Venetiarum, Bavariae, Imperii, a także definitywnie już pokonana Tyrannis Mahometica. 
Wśród zachowanych w komplecie źródłowym dramatów jest też sztuka o tematyce misyjnej, Mulier fortis Staudta ${ }^{51}$. Przedstawia ona historię męczeństwa japońskiej damy, Hosokawa Tama, która pod nieobecność męża nawraca się na chrześcijaństwo, budząc tym jego gniew. Głównym tematem spektaklu jest stałość jej wiary: kluczową rolę odgrywa tu alegoryczna Constantia. Postaci tej powierzony jest także kończący I akt chorus, który de facto jest rozbudowaną arią da capo:

Chorus I.

„Constantia docet symbolice humanum animum adversis esse superiorem”.

\begin{tabular}{|c|c|c|}
\hline $\begin{array}{l}\text { „Scena refert campum, in } \\
\text { cuius terminativo mare cum } \\
\text { scopulis”. }\end{array}$ & $\begin{array}{c}\text { „Luna luctatur cum nubibus et } \\
\text { eluctatur”. }\end{array}$ & $\begin{array}{c}\text { „Comparet scopulus, in quem } \\
\text { fluctus marini assiliunt”. }\end{array}$ \\
\hline 1. Fata premant, & 2. En, ut una & 3. Ridet minas, \\
\hline Hostes fremant, & Noctis luna & Et ruinas. \\
\hline Victor de illis animus est. & Nubium globo eripit se. & Victor in acquis scopulus stat. \\
\hline Per labores & En, ut alma & Mille luctus \\
\hline Per sudores & Sylvae palma & Volvunt fluctus, \\
\hline It serene. & Iugo obsessa, & Quos profundae \\
\hline Iubilat plene & Pondere pressa, & Concitant undae. \\
\hline Ad angores, & Eluctatur, & Ipse totus \\
\hline Ad tortores & Roboratur: & Non commotus \\
\hline Victor in illis animus est. & Mens ita fortis erigit se. & Victor in acquis scopulus stat. \\
\hline Hostes fremant, & Deprimatur, & Sic adversis \\
\hline Fata premant, & Prosternatur, & In diversis \\
\hline Victor in illis animus est. & Mens ita fortis erigit se. & Altior illis animus stat. \\
\hline Ritornello & Ritornello & Ritornello \\
\hline
\end{tabular}

Kolejnym zwrotkom arii towarzyszą odnotowane w didaskaliach sceny symboliczne, przedstawiające pojedynek księżyca z chmurą oraz skałę opierającą się żywiołowi wód. Treść obu przedstawień zapowiada przyszłe wydarzenia z życia męczennicy: jej niewieścią siłę powstrzyma wprawdzie na jakiś czas śmiercionośna zawiść małżonka, jednak stałość jej wiary ostatecznie pokona jego opór, doprowadzając również jego samego do skruchy i nawrócenia. Chyba nieprzypadkowym skojarzeniem z tą ostatnią metaforą jest jeszcze jedna rycina znajdująca się w Imago primi saeculi. Przedstawia ona za pomocą podobnej symboliki doświadczenie misji, a treść emblematyczną opatruje adekwatnym cytatem z Ksiegi Hioba (il. 7).

5I Mulier fortis cuius pretium de ultimis finibus sive Gratia Regni Tango Regina Exantlantis pro Christo aerumnis clara..., Wien 1698. A-Wn, Sammlung von Handschriften und alten Drucken, Cod. 9812/7. Por. edycję krytyczną tego dramatu, wyd. Walter Pass, Fumiko Niiyama-Kalicki, Graz 2000 (= Denkmäler der Tonkunst in Österreich I52). 


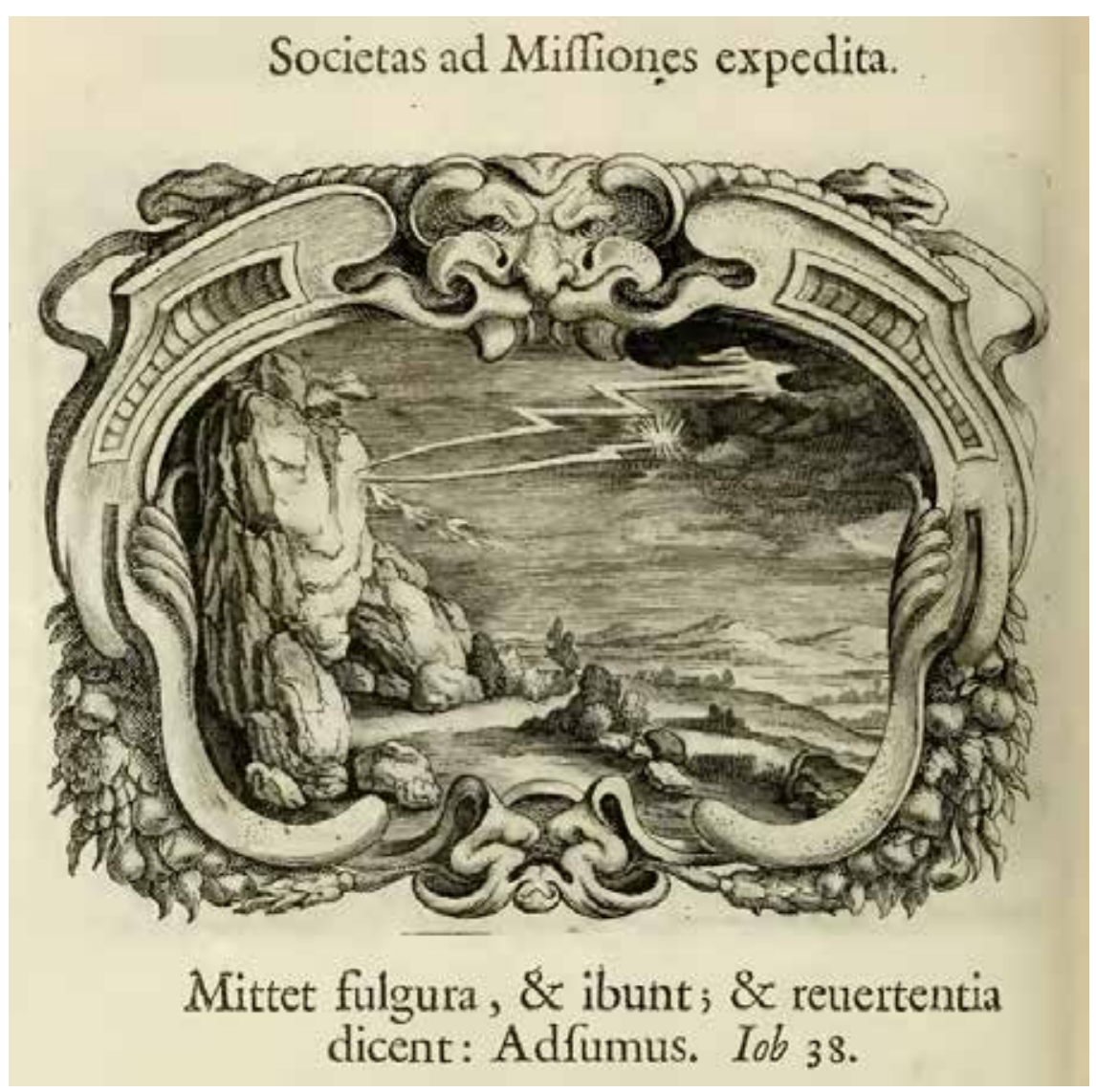

Il. 7. Imago primi saeculi Societatis Iesu..., op. cit., s. 324 .

Z powyższych przykładów można wnioskować, że pojawiająca się w jezuickich dramatach szkolnych muzyka była podporządkowana nie tylko bezpośrednio treści słownej, lecz także przekazowi wizualnemu, przemawiającemu za pomocą odpowiednio dobranej scenografii. Służyła więc nie tylko potęgowaniu perswazyjności umuzycznionego słowa, ale też intensyfikacji doświadczeń wzrokowych, stanowiących medium najbardziej chyba atrakcyjne dla poznania zmysłowego. Jeśli istotnie pełniła ona funkcję podrzędną względem przekazu wizualnego, to może wcale nie musi nam być aż tak szkoda, że w zdecydowanej większości do naszych czasów się nie zachowała. Stanowiła ona jednak nośnik - vehiculum treści wizualnych, była więc integralnym komponentem dzieła scenicznego i służyła synestetycznej poetyce jezuickiego dramatu i jego perswazyjnej retoryce. 
THE MUSIC IN SERVICE OF VISUAL COMMUNICATION

IN JESUIT SCHOOL DRAMA

One of the most important element of the Jesuit culture was the school drama, which combines elements of many arts into one synesthethic whole, proved to be a particularly valuable vehicle of artistic, educational and formative persuasion. To achieve its objectives, Jesuit authors applied elements of psychological introspection in their spectacles, in the form of visualisations of individual emotional states as well as solutions to those states that appeared in the course of dramatic action.

Comparing three different kinds of theatrical sources: periochai (action summaries distributed among the audience), libretti and the full music scores (coming almost exclusively from Vienna college), it is possible to discuss the music layer of individual spectacles, especially if by comparing various sources we reconstruct the methodology of encoding musical content, which varies from one group of sources to another, but betrays a rather logical general strategy.

The paper discuss how and in which way the music was used as a support of the visual communication in the spectacles played in central-European Jesuit colleges, concerning the topic of the overseas missions of the Society. For instance, the sections referred in the periochai as the choruses are actually extensive scenes consisting of a dozen or more episodes and musically completely independent. Where musical sequences are incorporated into the main action of the drama, they are shorter and complementary to the recited sections of the libretto.

Tomasz Jéz

Dr hab. Tomasz Jeż studiował muzykologię w Warszawie, Getyndze i Berlinie. Po promocji doktorskiej (2002) został zatrudniony w Instytucie Muzykologii UW na stanowisku adiunkta. W ramach programu „Kolumb” Fundacji na rzecz Nauki Polskiej odbył staż naukowy w Rzymie (2007/8). Jest autorem trzech książek i 60 artykułów, poświęconych zagadnieniom źródłoznawczym i ideowym aspektom kultury muzycznej. Jego głównym polem badań jest kultura muzyczna Śląska i Rzeczpospolitej Obojga Narodów w XVI-XVIII wieku. tomasz.jez@uw.edu.pl

\title{
Archiwalne zeszyty „Muzyki”
}

\author{
www.ispan.pl/pl/ mydawnictwa/czasopisma \\ iswydawnictwo@ispan.pl
}

